\title{
Pearls \& Oy-sters: Challenging diagnosis of Gerstmann-Sträussler-Scheinker disease
}

\section{Clinical and imaging findings}

Min Ju Kang, MD, Jeewon Suh, MD, Seong Soo An, PhD, SangYun Kim, MD, PhD, and Young Ho Park, MD, PhD

Neurology ${ }^{\circledR}$ 2019;92:101-103. doi:10.1212/WNL.0000000000006730
Correspondence

Dr. Park

kumimesy@snubh.org

Figure Brain MRI and PRNP sequences of the patient and his mother

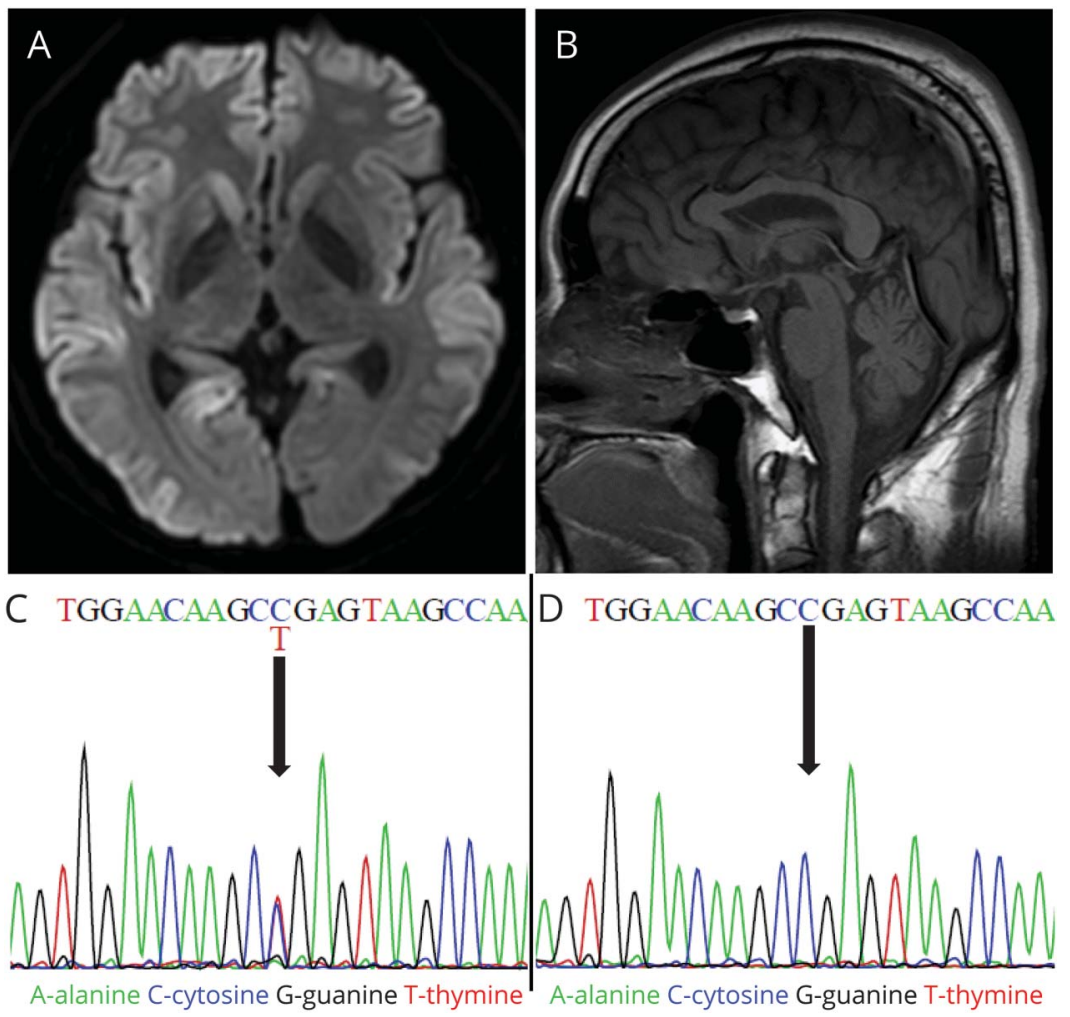

(A) Axial diffusion-weighted imaging of the patient shows marked high signal intensities in the bilateral cortices, right caudate, and right anterior putamen. (B) Sagittal T1-weighted imaging of the patient shows mild cerebellar atrophy. (C) PRNP sequence of the patient reveals heterozygous substitution from $C$ to $T$ at position 305 of $P R N P$, resulting in amino acid change from proline to leucine at position 102 (P102L mutation). (D) PRNP sequence of his mother confirms absence of the P102L mutation.

\section{Pearls}

- Gerstmann-Sträussler-Scheinker disease (GSS) is a rare prion disease characterized by cerebellar ataxia with progressive cognitive decline.

- GSS is caused by a mutation within the prion protein gene (PRNP), which commonly exhibits an autosomal dominant inheritance pattern. However, a significant portion of previously reported cases show no family history of the disease, and GSS may also occur through de novo mutation of PRNP.

\section{Oy-sters}

- GSS is clinically heterogeneous and has no characteristic features on imaging. GSS could be considered in patients experiencing unexplained ataxia and subsequent cognitive decline even in those without a family history of the disease.

From the Department of Neurology (M.J.K., J.S., S.K., Y.H.P.), Seoul National University College of Medicine and Seoul National University Bundang Hospital; and Department of Bionanotechnology (S.S.A.), Gachon University, Republic of Korea.

Go to Neurology.org/N for full disclosures. Funding information and disclosures deemed relevant by the authors, if any, are provided at the end of the article. 
A 49-year-old man, previously healthy, presented with a 1-year history of progressive gait disturbance, slurred speech, and clumsiness in both hands. He had no history of alcohol or drug abuse. He did not report any family history of neurodegenerative diseases. His 71-year-old mother and 74-year-old father, along with his 5 siblings ( 2 sisters and 3 brothers), were healthy and neurologically normal. Neurologic examination revealed dysarthria and ataxia. He could not perform tandem gait, and the Romberg test was negative. Motor and sensory functions were normal. Deep tendon reflexes were normal, and there were no pathologic reflexes or abnormal movements. He scored 22 on the Mini-Mental State Examination. Memory and executive function deficits were noted on neuropsychological tests. Routine laboratory tests were normal. There was no evidence for systemic vasculitis, paraneoplastic disorders, or autoimmune thyroiditis. Brain MRI performed 13 months after the onset of symptoms showed high signal intensities over the bilateral cortices, right anterior putamen, and right caudate, which were evident on diffusion-weighted imaging (DWI) and fluid-attenuated inversion recovery (FLAIR) imaging (figure). Mild cerebellar atrophy was noted on T1-weighted imaging (figure). EEG was normal without periodic synchronous discharges. Routine CSF analysis was unremarkable, but the CSF 14-3-3 protein was positive. Genetic testing showed heterozygous substitution from $\mathrm{C}$ to $\mathrm{T}$ at position 305 of PRNP, resulting in an amino acid change from proline to leucine at position 102 (P102L mutation) (figure). This confirmed the diagnosis of Gerstmann-Sträussler-Scheinker disease (GSS). Since there was no PRNP mutation in either parent (figure), de novo P102L mutation was suspected in the patient. His motor and verbal abilities rapidly declined. He became akinetic and mute 5 months after the initial visit.

\section{Discussion}

GSS is a hereditary prion disease characterized by prominent cerebellar ataxia accompanied by gradually progressive cognitive decline. ${ }^{1}$ A diagnosis is made by genetic testing to confirm PRNP mutation. ${ }^{2}$ Mutations in PRNP often exhibit an autosomal dominant inheritance pattern. However, prior studies including a European cohort study found that one-third of patients with GSS showed no family history of neurodegenerative disease. ${ }^{3}$ This was the case in our patient. Although we confirmed P012L mutation in our patient, PRNP mutation was not observed in the patient's parents. In our case, we observed high signal intensities over the bilateral cortices on DWI/ FLAIR imaging, which led to further testing for a prior proteinrelated disease and ultimately the diagnosis of GSS. To our knowledge, there has not been any systematic literature review investigating the family history of GSS and MRI findings.

Here, a systematic literature review was conducted to investigate the clinical manifestation, diagnostic test results, and presence of family history of GSS. Publications listed in PubMed between 2000 and 2017 were searched using the keyword "Gerstmann-Sträussler-Scheinker." Thirty-six case reports (a total of 85 patients) published in English were collected. $^{\text {e1-36 }}$ Clinical presentation and family history of these 85 patients, as well as our patient, are presented in table e-1 (doi.org/10.5061/dryad.2p6m6nt). Fourteen of 85 cases $(16.5 \%)$ did not have any family history of GSS. However, it is worth noting that some of these cases had negative family history due to either missing informatio$\mathrm{n}^{\mathrm{e} 13, \mathrm{e} 21, \mathrm{e} 22}$ or early death of first-degree relatives. ${ }^{\text {e22 }}$ Among

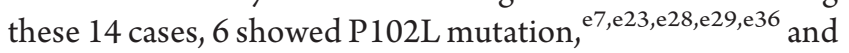
the remaining 8 showed different mutations (A133V, ${ }^{\mathrm{e} 8}$ D202N, ${ }^{\text {e9 }} \mathrm{Q} 217 \mathrm{R},{ }^{\mathrm{e} 13} \mathrm{P} 84 \mathrm{~S},{ }^{\mathrm{e} 21} \mathrm{~V} 176 \mathrm{G},{ }^{\mathrm{e} 22} \mathrm{Six}$ OPRI, ${ }^{\mathrm{e} 6}$ $\mathrm{Q} 212 \mathrm{P},{ }^{\mathrm{e} 33} \mathrm{G} 131 \mathrm{~V}^{\mathrm{e} 34}$ ). Because P102L mutation is known to have high penetrance, ${ }^{4}$ incomplete penetrance is likely not the cause of negative family history in the 6 patients with P102L mutation. Interestingly, 2 P102L-mutated patients, including our patient, were confirmed to have de novo mutation of PRNP by sequencing in both parents. ${ }^{5}$ However, the mutations exhibited by the remaining 8 patients were not found in patients with GSS with positive family history, suggesting the possibility of incomplete penetrance in these 8 patients. Typically, the genetic prion disease is only considered if the patient has a family history of similar disorders. However, an analysis of literature regarding GSS revealed that a significant proportion of patients with GSS did not have a family history of the disease.

With regard to MRI results, a substantial portion of patients with GSS showed nonspecific findings. Table e-2 (doi.org/10. $5061 /$ dryad.2p6m6nt) describes the MRI findings of 63 patients with GSS who underwent brain MRI. Twenty-seven of 63 patients $(42.9 \%)$ only exhibited either cortical atrophy or cerebellar atrophy. Thirteen patients (20.6\%) displayed high signal abnormalities in the cortex, caudate nucleus, or putamen, which were similar to the imaging findings in sporadic Creutzfeldt-Jakob disease. ${ }^{6}$

GSS can manifest various signs and symptoms (table e-1, doi. org/10.5061/dryad.2p6m6nt). The initial symptoms were reported in 66 patients, of which 15 patients $(22.7 \%)$ presented with paresthesia or numbness, depression, convulsion, and deafness and did not present with ataxia or cerebellar signs at the initial symptoms. Cerebellar dysfunction, however, was observed in all patients at advanced stages of disease. According to our analysis, there seems to be some variability in the initial phenotypic presentation, especially in the early stages of GSS, lacking classical symptoms of other prior protein diseases, like cerebellar dysfunction.

GSS can be challenging to diagnose due to the wide spectrum of clinical phenotypes and imaging findings, as well as ambiguity in family history. Thus, PRNP genetic testing for GSS should be considered in patients with ataxia or cognitive impairment of unknown etiology, even in those without family history.

\section{Author contributions}

Dr. Kang: study concept and design, acquisition of data, analysis and interpretation. Dr. Suh: acquisition of data. Dr. An: analysis and interpretation. Dr. Kim: critical revision of the 
manuscript for important intellectual content. Dr. Park: study concept and design, critical revision of manuscript for important intellectual content, study supervision.

\section{Study funding}

No targeted funding reported.

\section{Disclosure}

The authors report no disclosures relevant to the manuscript. Go to Neurology.org/N for full disclosures.

\section{References}

1. Webb TE, Poulter M, Beck J, et al. Phenotypic heterogeneity and genetic modification of P102L inherited prion disease in an international series. Brain 2008;131: 2632-2646.

2. Mead S. Prion disease genetics. Eur J Hum Genet 2006;14:273-281.

3. Kovacs GG, Puopolo M, Ladogana A, et al. Genetic prion disease: the EUROCJD experience. Hum Genet 2005;118:166-174.

4. Minikel EV, Vallabh SM, Lek M, et al. Quantifying prion disease penetrance using large population control cohorts. Sci Transl Med 2016;8:322-329.

5. Kojovic M, Glavac D, Ozek B, Zupan A, Popovic M. De novo P102L mutation in a patient with Gerstmann-Straussler-Scheinker disease. Eur J Neurol 2011;18: e152-e153.

6. Dagvadorj A, Petersen RB, Lee HS, et al. Spontaneous mutations in the prion protein gene causing transmissible spongiform encephalopathy. Ann Neurol 2002;52:355-359.

\section{Subspecialty Alerts by E-mail!}

Customize your online journal experience by signing up for e-mail alerts related to your subspecialty or area of interest. Access this free service by clicking on the "My Alerts" link on the home page. An extensive list of subspecialties, methods, and study design choices will be available for you to choose from-allowing you priority alerts to cutting-edge research in your field!

\section{Share Your Artistic Expressions in Neurology 'Visions'}

AAN members are urged to submit medically or scientifically related artistic images, such as photographs, photomicrographs, and paintings, to the "Visions" section of Neurology ${ }^{\oplus}$. These images are creative in nature, rather than the medically instructive images published in the NeuroImages section. The image or series of up to six images may be black and white or color and must fit into one published journal page. Accompanying description should be 100 words or less; the title should be a maximum of 96 characters including spaces and punctuation.

Please access the Author Center at NPub.org/authors for full submission information.

\section{The AAN Has Your Back!}

Every day, the AAN is fighting for you. From actively lobbying members of Congress for common sense legislation, to meeting with regulators to demonstrate the value of neurology and reduce regulatory hassles, the Academy is forcefully countering any threats to your profession and patient access to care. Learn more at AAN.com/policy-and-guidelines/advocacy, read the bimonthly Capitol Hill Report and monthly AANnews member magazine, and respond to Advocacy Action Alert emails when we invite you to share your voice with Congress.

Get into the conversation at \#AANAdvocacy. 


\title{
Neurology
}

\author{
Pearls \& Oy-sters: Challenging diagnosis of Gerstmann-Sträussler-Scheinker disease: \\ Clinical and imaging findings \\ Min Ju Kang, Jeewon Suh, Seong Soo An, et al. \\ Neurology 2019;92;101-103 \\ DOI 10.1212/WNL.0000000000006730
}

\section{This information is current as of January 7, 2019}

\section{Updated Information \& Services}

References

Citations

Subspecialty Collections

Permissions \& Licensing

Reprints including high resolution figures, can be found at: http://n.neurology.org/content/92/2/101.full

This article cites 6 articles, 0 of which you can access for free at: http://n.neurology.org/content/92/2/101.full\#ref-list-1

This article has been cited by 2 HighWire-hosted articles: http://n.neurology.org/content/92/2/101.full\#\#otherarticles

This article, along with others on similar topics, appears in the following collection(s):

All Cognitive Disorders/Dementia

http://n.neurology.org/cgi/collection/all_cognitive_disorders_dementia All Genetics

http://n.neurology.org/cgi/collection/all_genetics

All Neuropsychology/Behavior

http://n.neurology.org/cgi/collection/all_neuropsychology_behavior MRI

http://n.neurology.org/cgi/collection/mri

Prion disease; see Infections/prion

http://n.neurology.org/cgi/collection/prion_disease

Information about reproducing this article in parts (figures,tables) or in its entirety can be found online at:

http://www.neurology.org/about/about_the_journal\#permissions

Information about ordering reprints can be found online:

http://n.neurology.org/subscribers/advertise

Neurology ${ }^{\circledR}$ is the official journal of the American Academy of Neurology. Published continuously since 1951 , it is now a weekly with 48 issues per year. Copyright @ 2019 American Academy of Neurology. All rights reserved. Print ISSN: 0028-3878. Online ISSN: 1526-632X.

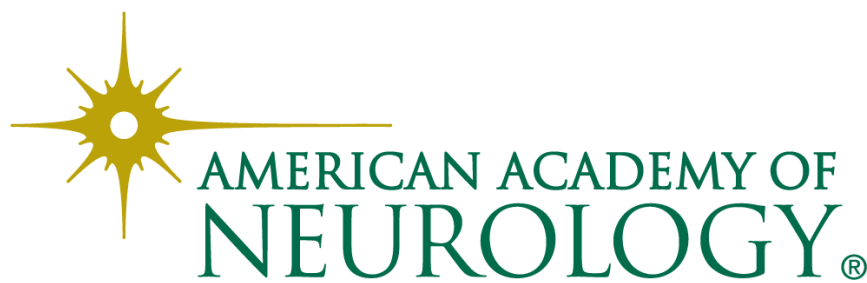

